Ann. Biol. anim. Bioch. Biophys., I975, 15 (2), 427-436.

\title{
CONTROL OF THE OESTROUS GYCLE IN FRIESIAN HEIFERS WITH ICI 80,996
}

A synthetic PRostaglandin ANALOGUe, STRUCTURALl, RELATED TO PGF $2 \alpha$

\author{
M. J. COOPER and L. E. A. ROWSON*
}

I. C. I., Pharmaceutical Division, Alderley Park, Macclesfield, Cheshire SK10 $4 T G$ (U. K.)

* A. R. C., Unit of Reproductive Physiology and Biochemistry,

Animal Research Station, 309 Hutingdon Road,

Cambridge, $C B 3$ OJQ (U.K.)

\section{SUMMARY}

Two single intramuscular injections of $500 \mu \mathrm{g}$ of ICI 80,996 separated by a period of I I days was shown to be an effective method of controlling oestrus and ovulation in cycling heifers. One hundred and seventy one of one hundred and seventy five heifers exhibited oestrus between 48 and 96 hours, and no fewer than I59 of these came into heat between 48 and 72 hours after the second injection. Changes in plasma concentrations of LH, progesterone and oestradiol-I 33 around the oestrus following luteolysis induced by ICI 80,996 , were closely similar to those occurring around a spontaneous oestrus. The corpus luteum formed following ovulation after the controlled heat was fully functional and the oestrous cycle following treatment was of normal length.

These results suggest that fertility associated with the controlled ovulation is likely to be normal and this is confirmed by preliminary conception data.

\section{INTRODUC'TION}

It is now well established that natural prostaglandin $F_{2 \alpha}$, administered by various routes can induce functional and morphological regression of the corpus luteum (1uteolysis) in a wide variety of species. Rowson et al. (I972) reported that doses as low as $0.5 \mathrm{mg} \mathrm{F}_{2 \alpha}$ administered on 2 consecutive days by the intra-uterine route could induce luteolysis in the bovine. These workers injected the prostaglandin via a thin metal catheter into the uterine horn ipsilateral to the ovary bearing the corpus luteum and showed that luteolysis was followed by apparently normal oestrus and ovulation 2-4 days after the first injection. Subsequent reports have shown that much higher single doses of $\mathrm{PGF}_{2}$ are equally effective by the intramuscular, subcutaneous, and even the intra-vaginal route (LIEHR et al., I972; Lours et al., I973 ; LAUDERDALE et al., I974). 
These reports are generally in agreement that the dose of $\mathrm{PGF}_{2 \alpha}$ required to induce luteolysis in cattle by a single parenteral administration is about $30 \mathrm{mg}$.

A new series of compounds, the 16 -aryloxprostaglandins have now been synthesized (BINDER et al., I974) and tested in a number of species. A preliminary report (Dukes et al., I974) shows several of them to be extremely potent luteolytic agents and highly selective in their pharmacological activity. This selectivity gives them a very wide margin of sefety in both laboratory and domestic species.

Two compounds in this series, ICI 79,939 and ICI 80,996 have already been used in cattle. TERviT et al. (I973) have shown the former to be luteolytic in cattle at a single intramuscular dose of I $\mathrm{mg}$ or less, while COOPER (I974) and CoOPER and FURR (I974) have reported the successful use of a single dose of $500 \mu \mathrm{g}$ of the latter. All workers are agreed that the corpus luteum is unaffected by prostaglandin treatment during the first 4-5 days of the cycle, and that prostaglandin administration has no apparent effect after spontaneous luteal regression has begun. Thus a single injection of any prostaglandin, given to a group of animals cycling at random will only be followed by oestrus and ovulation in a proportion of them.

To overcome this difficulty a simple regime of treatment has been described by COOPER (I974) and COOPER and FURR (1974) consisting of 2 single injections of ICI 80,996 separated by a period of IO-I2 days. At the time of the second injection all animals are sensitive to the prostaglandin and respond with oestrus and ovulation.

This paper describes studies to investigate the efficacy of this regime and some of the endocrine changes which occur during oestrus synchronisation.

\section{MATERIALS AND METHODS}

I. - Forty five cycling Friesian heifers were treated with 2 single intramuscular injections of $500 \mu \mathrm{g}$ ICI 80,996 separated by i I days and their responses to treatment were examined in some detail. The previous oestrus dates of all these animals were known, although they were not selected for treatment on this basis but were injected at random.

Heifers were run in small groups with vasectomised bulls wearing 'chin-ball' marking devices and oestrus detection relied on this and regular observations by an experienced cowman. Rectal palpations were performed before and after each prostaglandin injection to record morphological changes in the reproductive tract, special attention being paid to :

I. Uterine tone and size.

2. Follicular development.

3. Size and nature of the corpora lutea.

Cervical mucus samples were also taken and examined for spinnbarkeit (the capacity of semi-liquids to be drawn into threads) and for fern patterns in dried smears. Ovulation was diagnosed by recording the disappearance of a follicle of pre-ovulatory size, the subsequent palpation of a characteristic depression on the ovarian surface, and the palpation later of a corpus luteum on the same ovary.

Using these methods it was possible to monitor luteal regression, the changes associated with oestrus, and ovulation after each injection. These findings were used to confirm observations of oestrous behaviour.

II. - One hundred and thirty further Friesian heifers have been treated in experiments designed to examine the fertility of the synchronised heat. They also received 2 single injections of $500 \mu \mathrm{g} 80,996$ separated by i I days. Observations of oestrous behaviour were carried out as in the first experiment, but no other interference was performed except in those animals in which behavioural symptoms left reason for doubt. In these cases cervical mucus samples were collected and the animals were also examined per rectum. 
1II. - Seven Friesian heifers were used to examine the endocrine changes associated with this treatment regime. Each was selected to be in the mid-luteal phase of the cycle at the start of the experiment and each received the same treatment with ICI 80,996 as the animals in experiments I and II. The heifers were restrained in a byre until ro days after the second injection and their jugular veins were cannulated to facilitate regular bleeding. Blood samples were taken in to heparinized syringes, centrifuged at $5^{\circ} \mathrm{C}$, and the plasma separated, frozen and stored for hormone assay. Samples were taken twice before the first injection, every two hours for 96 hours after each injection, daily or twice daily during the remainder of the experiment and every other day throughout the next oestrous cycle. Clinical changes were monitored by regular rectal palpations and mucus sampling as described in Experiment I and the onset of oestrus was judged on the basis of these findings since no opportunity was available to observe behavioural changes.

Plasma concentrations of $\mathrm{LH}$, oestradiol-I $7 \beta$, and progesterone were measured by radioimmunoassay. LH was assayed by a modification of the double antibody procedure of NISWENDER

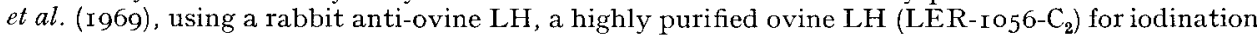
and ovine LH (NIH-LH-S 14 ) as a standard.

Measurement of both oestradiol-1 $7 \beta$ and progesterone was carried out by Dr. Hilary DoBson at Liverpool University. Oestradiol-I $7 \beta$ was estimated in ether extracts of plasma without chromatography using a specific rabbit antiserum prepared against oestradiol-I $73-6-$ carboxymethyloxime-bovine serum albumin (DoBson and DEAN, 1974).

Progesterone was estimated by radioimmunoassay in hexane extracts of plasma using a goat antiserum prepared against progesterone I I- $\alpha$-succinyl-bovine serum albumin (FURR, I973).

\section{RESUL'TS}

Figure I and table I show the responses recorded in the 45 heifers monitored in detail, while figure 2 and table 2 show the degree of synchronisation achieved in the total number of heifers treated. It is interesting to note in figure $I$ that no animal treated before the $5^{\text {th }}$ days of the cycle showed heat after the first injection, while only 2 animals are recorded as having failed to show a synchronised heat after the second injection. It is also interesting that the return to oestrus after the second injection is rather more prompt and better synchronised than after the first.

TABLE I

Responses of 45 heifers examined in detail

\begin{tabular}{|c|c|c|c|c|c|}
\hline \multicolumn{2}{|c|}{ No. heifers in oestrus } & \multicolumn{3}{|c|}{ No, heifers ovulating } & \multirow{3}{*}{ Failures } \\
\hline Hours aft & injection & \multicolumn{3}{|c|}{ Hours after 2 nd injection } & \\
\hline $48-72$ & $72-96$ & $48-72$ & $72-96$ & $96-120$ & \\
\hline 39 & 4 & $\ell_{t}$ & 34 & 5 & 2 \\
\hline
\end{tabular}

This has been a consistant finding during studies on this synchronising technique. All heifers in this experiment were observed after the experimental period and were found to exhibit a subsequent cycle of normal length. The pattern of oestrous responses shown in figure $I$ and table $I$ are repeated in figure 2 and table 2 . The majo- 
Synchronisation of Oestrus in Heifers with ICI 80,996.

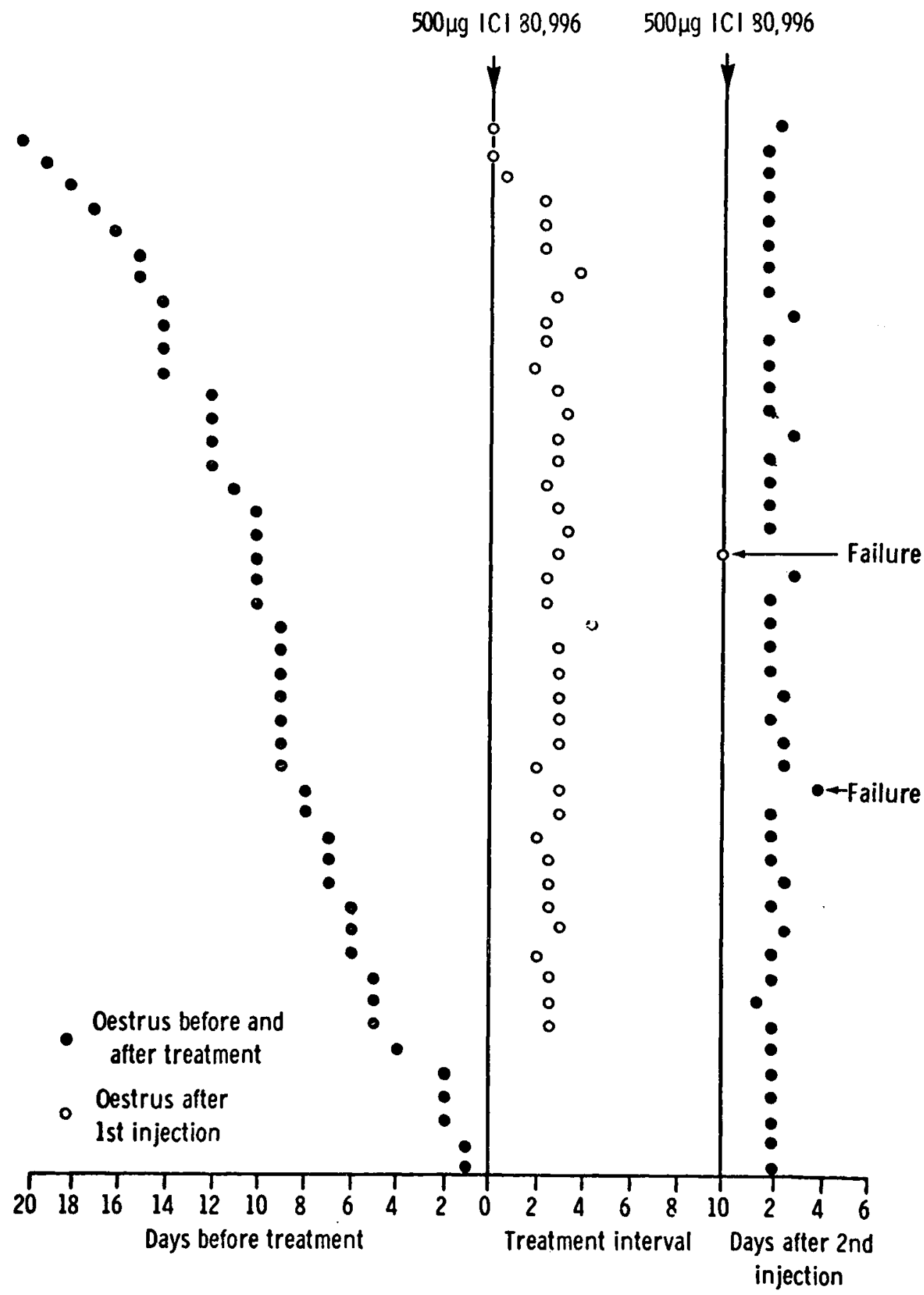

FIG. I 
rity of heifers showed most of their oestrous behaviour between 48 and 72 hours after the treatment. No animals were seen in heat 36 hours after the second injection, but a small number ( 14 p. roo) were found to be in standing oestrus or had been served by the vasectomised bull when examined at 48 hours. Similarly a number of heifers were still showing some heat behaviour at 72 hours and a further number ( 7 p. IOo) did not come into heat until between 72 and 96 hours after the second injection. However, as shown in figure 2, the majority of the oestrous behaviour occured between 48 and 72 hours after this treatment.

Synchronisation Success.

(4 heifers failed to synchronise)

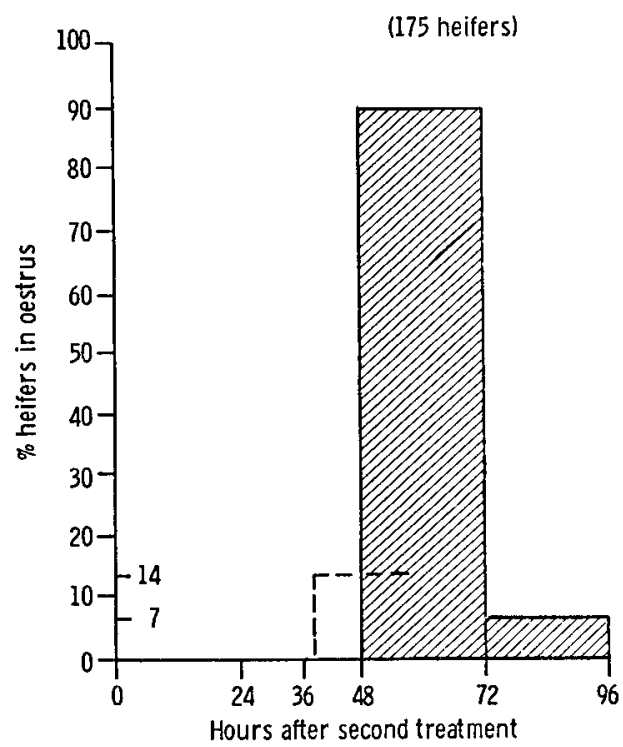

FIG. 2

TABLE, 2

Otstrous responses in total no. heifers synchronised

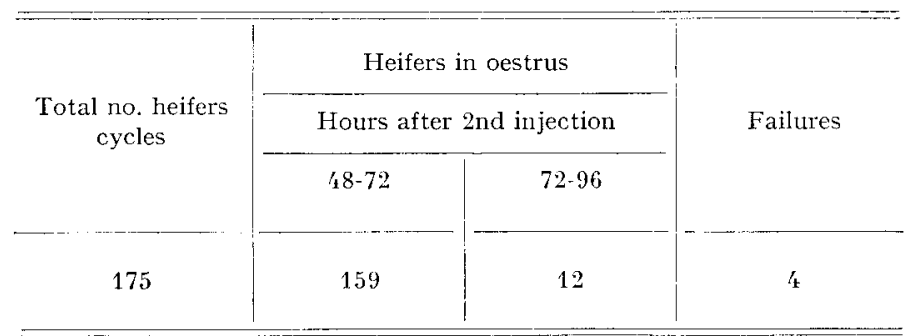

In addition to the failures recorded, a further 2 heifers were noted as showing inconclusive symptoms of oestrus. However, these animals were found to have ovulated at the expected time and entered cycles of normal length. 


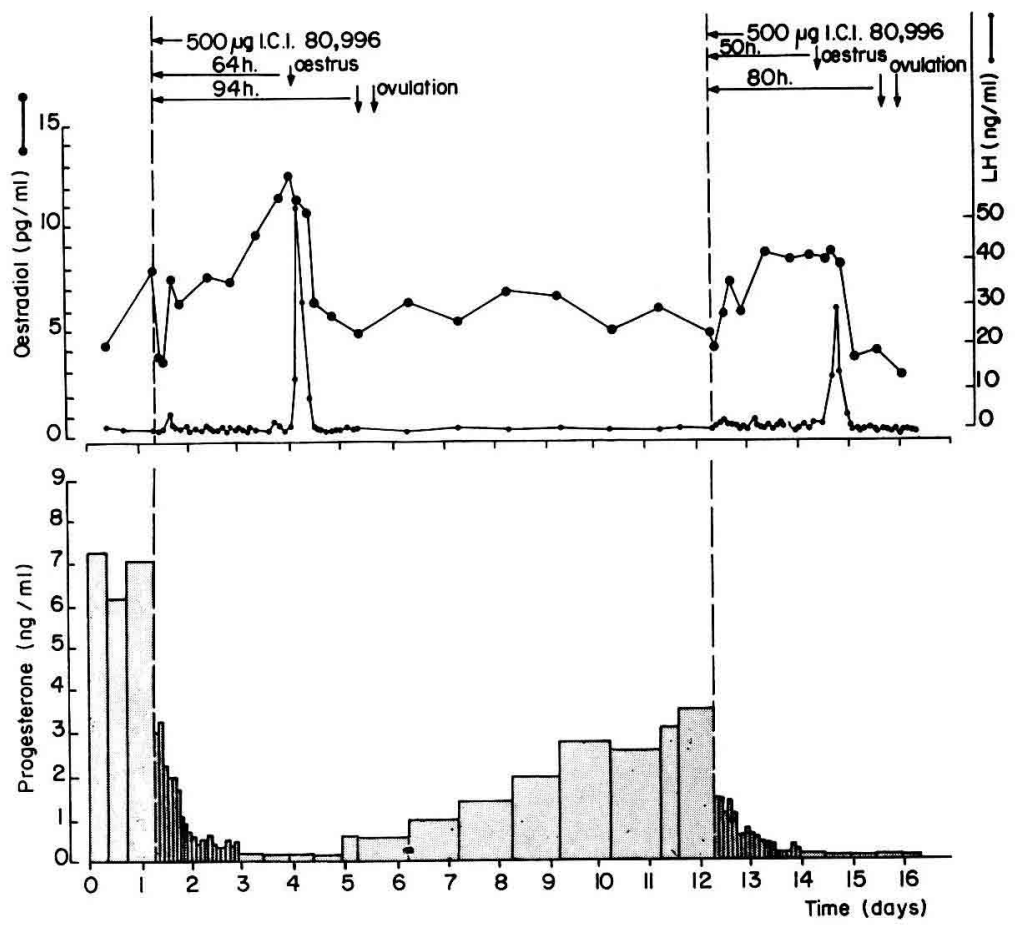

FIG. 3

Post Treatment Cycle is Normal.

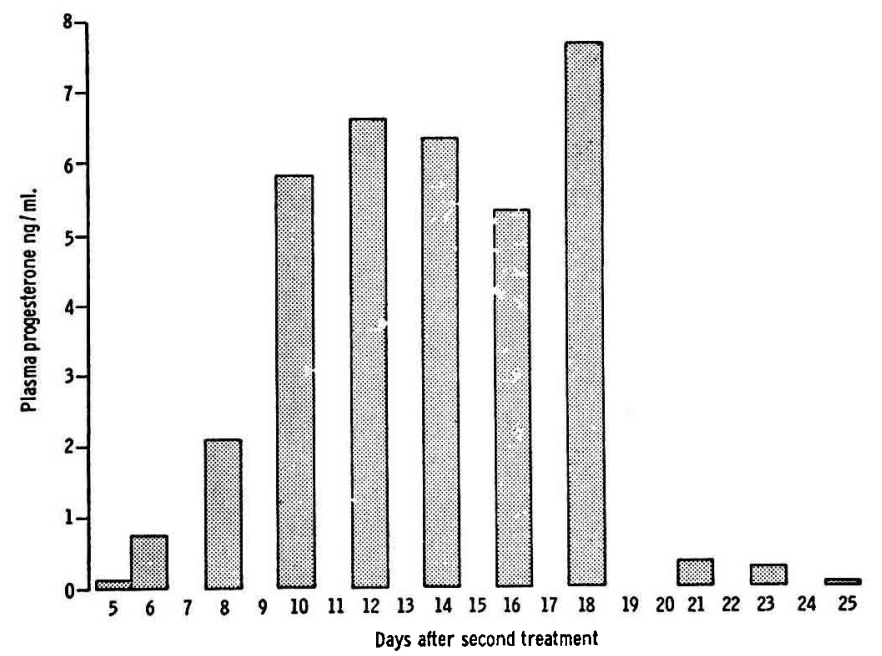

FIG. 4 

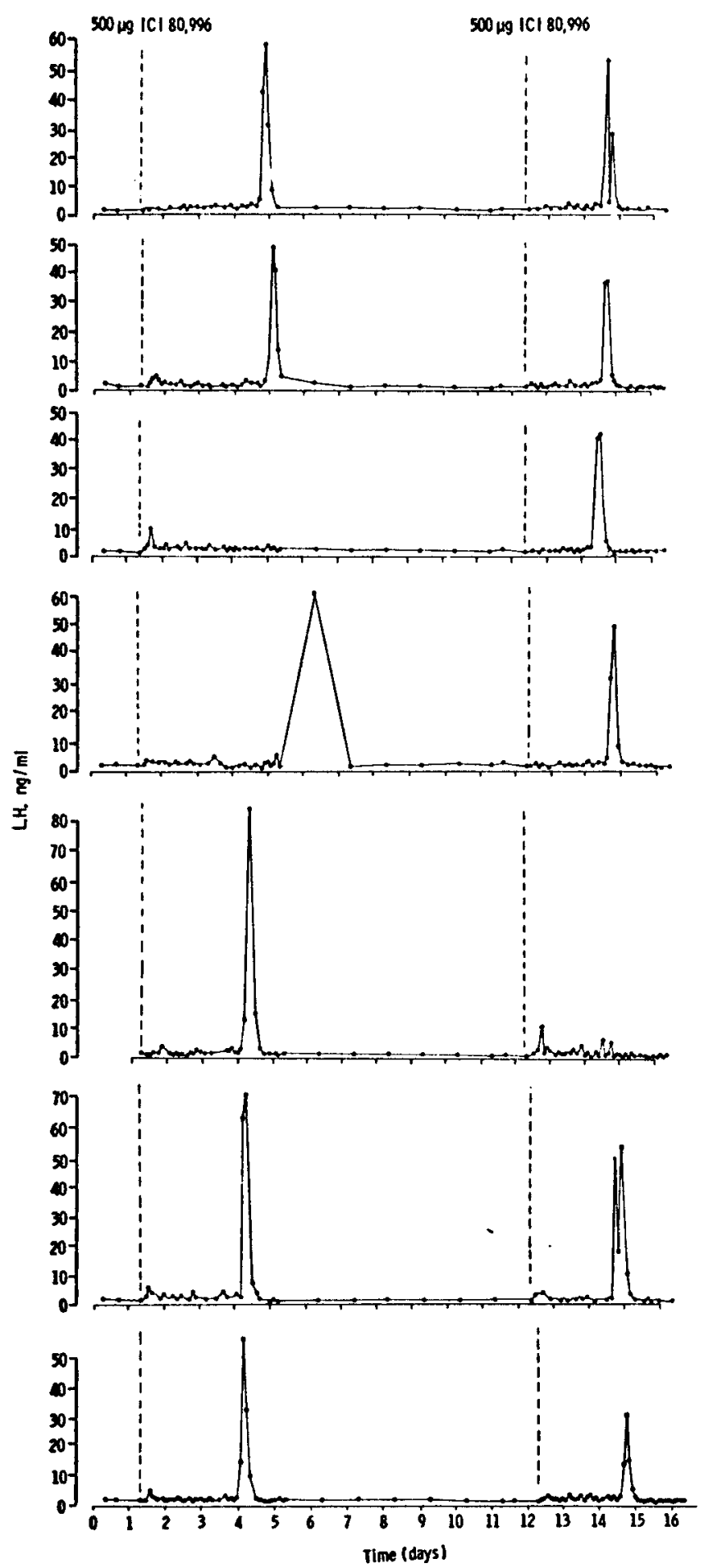

FIG. 5 
Figures 3 and 4 show the endocrine changes in one of the 7 heifers in Experiment 3 , and figure 5 the $\mathrm{LH}$ concentrations in all 7 . Six of the seven heifers showed changes very similar to those shown in figures 3 and 4 while the 7 th did not have an elevated plasma $\mathrm{L}_{1} \mathrm{H}$ (as demonstrated in fig. 5) and consequently failed to ovulate after the second injection; it appeared to become anoestrous.

Administration of ICI 80,996 was followed by an extremely rapid reduction in circulating plasma progesterone concentrations which reached basal values within about 24 hours. This was followed by follicular development and a consequent rise in the concentration of the plasma oestradiol, the peak of the oestradiol secretion being associated with the pre-ovulatory surge of LH. In one animal this surge was not recorded after the first injection and reference to the clinical data shows oestrus to have occurred after the period of frequent sampling. In all 7 animals these hormone changes were found to be very well correlated with the recorded clinical findings.

\section{DISCUSSION}

These results show clearly that the administration of 2 injections of ICI 80,996 separated by II days, is an extremely effective method of controlling oestrus in cycling Friesian heifers.

The endocrine changes reported here at oestrus following ICI 80,996-induced luteolysis are similar, both in magnitude and time course to those reported to occur around a spontaneous oestrus (GLencross et al., I973; Dobsor, I973; NANCARRow et al., I973). This fact, and the observation that the corpus luteum of the subsequent cycle is fully functional is good evidence for the normality of the controlled oestrus and ovulation. The hormone changes are also similar to those reported to occur after the administration of prostaglandin $\mathrm{F}_{2 \alpha}$ during the luteal phase of the cycle (Lours et al., I973; Louis et al., I974; OXENDER et al., I974). Further work with this technique at field trial in lactating cattle has shown the superior synchronisation after the second as compared to the first injection to be a consistent feature of the response. However, in these field trials the distribution of the oestrous response appears to be slightly wider and a little more delayed. The excellent results recorded here may have been enhanced by the following factors:

I. The heifers were all the same breed and age.

2. The work was all done in spring and early summer while the animals were on a high plane of nutrition.

3. All the heifers were judged to be cycling.

4. They were constantly in the presence of vasectomised bulls.

In spite of these factors some animals did fail to respond, and under field conditions a failure rate of about $5 \mathrm{p}$. Ioo is not unusual. Animals failing to respond are thought to fall into one of the following categories :

I. Animals which are completely unaffected by the treatment, perhaps because of inadequate absorption and distribution of the drug.

2. Those which exhibit a delayed response to the first injection (perhaps due to treatment near the critical fifth day of the cycle) and thus are out of phase at the time of the second. 
3. Heifers undergoing only partial luteolysis after treatment which may show some symptoms of oestrus but do not ovulate, and go on to complete an uninterrupted cycle (COOPER, FURR, unpublished data).

In spite of these minor problems it is clear that this simple and extremely practical technique provides very good control of the oestrous cycle in heifers, and the endocrine data demonstrate how precise this can be under experimental circumstances.

The objective of any synchronising technique must be to produce "normal " conception rates following a single insemination at a fixed time, and it is clear from the distribution of oestrous behaviour recorded here that this is unlikely to be possible with prostaglandins alone. However, preliminary field trial results (COOPER and JACKSON, unpublished data) show that two fixed time inseminations at 72 and 96 hours after the second injection of prostaglandin yield conception rates equal to those of control animals. If the success rate of a properly timed single insemination proves to be only slightly inferior it may still be economically viable under many management systems.

The conclusions which can be drawn from this work are that the treatment described is an effective method of controlling oestrus in cycling cattle, particularly heifers. It is simple to administer and induces luteolysis followed by a heat which is both clinically and hormonally very similar to a spontaneous heat. Ovulation occurs at the usual time after this induced oestrus and is followed by the formation of a fully functional corpus luteum and therefore a subsequent cycle of normal length. All the preliminary evidence suggests that fertility at this controlled ovulation is normal, although the optimum insemination time or times have yet to be defined at field trial

\title{
Colloque : Control of sexual cycles in domestic animals
} october 27-30, 1974, Nouzilly.

\author{
RÉSUMÉ \\ CONTRÔLE DU CXCLE GSTRIEN CHEZ LES GÉNISSES FRISONNES \\ A L'AIDE D'UN ANALOGUE DE PGF ${ }_{2} \alpha$ : ICI 80.996
}

Deux injections intramusculaires de $500 \mu \mathrm{g}$ de ICI 80996 espacées de I I jours constituent une méthode efficace pour contrôler l'oestrus et l'ovulation chez les génisses cycliques. Cent soixante et onze génisses (sur I 75 traitées) ont manifesté un cestrus de 48 à 96 heures après la scconde injection; I 59 de celles-ci ont été en chaleurs entre la $48^{\mathrm{e}}$ et $7_{2}$ e heure. Les variations des concentrations plasmatiques de $\mathbf{L H}$, progestérone et d'œstradiol-i $7 \beta$ au moment de l'œestrus ont été semblables à celles observées autour d'un cestrus spontané. Le corps jaune formé par suite de l'ovulation lors de la chaleur contrôlée était complètement fonctionnel et le cycle ostrien suivant le traitement était de durée normale.

Ces résultats suggèrent que la fertilité associée à l'ovulation contrôlée est vraisemblablement normale et ceci est confirmé par des résultats préliminaires.

\section{REFERENCES}

Binder D., Bowler J., Brown E. D., Crossley N. S., Hutron J., Senior J., Slater I., WILkINSON P., WRIGHT N. C. A., r974. I6-aryloxyprostaglandins : a new class of potent luteolytic agent Prostaglandins, 6, 87-9o. 
Cooper M. J., 1974. Control of oestrous cycles of heifers with a synthetic prostaglandin analogue. Vet. Rec., 95, 200-203.

Cooper M. J., Furr B. J. A., I974. The role of prostaglandins in animal breeding. Iet. Rec., 94, I6r.

Dobson H., DeAN P. D. G., I974. Radioimmunoassay oestrone, oestradiol-I $7 \alpha-17 \beta$ in bovine plasma during the oestrous cycle and last stages of pregnancy. J. Endocr., 61, 479-486.

Dobson H., 1973. Ph. D. Thesis, Liverpool University.

Dukes M., Russell W., Walpole A. L., 1974. Potent luteolytic agents related to prostaglandin $\mathrm{F}_{2 \alpha}$. Nature, 250, 330-331.

FURR B. J. A., I973. Radioimmunoassay of progesterone in peripheral plasma of the domestic fowl in various physiological states and in follicular venous plasma. Acta. Endocr., Copenh., 72, 89-Ioo.

Glencross R. G., Munro I. B., Senior B. E., Pope G. S., 1972. Concentrations of oestradiol-17\%, oestrone and progesterone in jugular venous plasma of cows during the oestrous cycle and in early pregnancy. Acto. Endocr., Copenh., 73, 374-384.

Lauderdale J. W., Seguin B. E., Stellflug J. N., Chenault J. R., Thatcher W. W., Vincent

C. K., Loyancano A. F., 1974. Fertility of cattle following $\mathrm{PGF}_{2 \alpha}$ injection. J. Anim. Sci., 38, 964-967.

Liehr R. A., Marion G. B., OLSEN H. H., I972. Effects of prostaglandin on cattle oestrous cycles. J. Anim. Sci, 35, 247.

Louis T. M., Hafs H. D., Morrow D. A., I974. Intrauterine administration of prostaglandin $F_{2 \alpha}$ in cows : Progesterone, oestrogen, LH, oestrus and ovulation. J. Anim. Sci., 38, 347-353.

Lovis T. M., Hafs H. D., Seguin B. E., I973. Progesterone, LH, oestrus and ovulation after prostaglandin $\mathrm{F}_{2 \alpha}$ in heifers. Proc. Soc. Exp. Biol. Med., 142, I52-I55.

Nancarrow C. D., Buckmaster J., Chamley W., Cox R. I., Cumming I. A., Cummins L., Drinan J. D., Findlay J. K., Goding J. R., Restall B. J., Schneider W., Thorburn G. D., I973. Hormonal changes around oestrus in the cow. J. Reprod. Fert., 32, 320-32I (Abstract).

Niswender G. D., Reichert L. E., Midgley A. R., Nalbandov A. V., ig69. Radioimmunoassay for bovine and ovine luteinizing hormone. Endocrinology, 84, I I66-1 I 73 .

Oxender W. D., Noden P. A., Louis T. M., Hafs H. I., I974. A review of prostaglandin $F_{2 \alpha}$ for ovulation control in cows and mares. Am.J. Vet. Res., 35, 996-roor.

Rowson L. E. A., Tervit H. R., Brand 'A., I972. The use of prostaglandins for synchronisation of oestrus in cattle. J. Reprod. Fert. 29, I45.

Tervit H. R., Rowson L. E. A., Brand A., I973. Synchronisation of oestrus in cattle using a prostaglandin $\mathrm{F}_{2 \alpha}$ analogue (ICI 79,939). J. Reprod. Fert., 34, I79-1 $8 \mathrm{I}$. 